\title{
Is Government Contestability an Integral Part of the Definition of Democracy? \\ $*$
}

\section{Abstract}

Is government contestability an integral part of the definition of democracy? This question concerns how we classify political systems in which, despite a formally open political structure, a dominant political group faces weak opposition from other political parties and civil society organizations - an indication of a low degree of government contestability. In Robert Dahl's polyarchy, contestability is an essential dimension of democracy and, as a result, one-party dominance is classified as an 'inclusive hegemony' outside his conception of democracy. For procedural definitions of democracy, however, dominant party systems are legitimate outcomes of electoral competition provided that there have been no formal restrictions to the exercise of civil and political rights. The article examines the boundaries between democracy and authoritarianism, broadens the notion of authoritarian controls to include soft manipulative practices and explains why government contestability should be regarded as a constitutive property of democracy.

* A revised version has been published in the Journal 'Politics' on 19 May 2016

\section{Keywords: democracy, authoritarianism, pluralism, Robert Dahl, hybrid regimes, dominant party systems}

Word Count: 7,963

The conceptual boundary separating democracy from authoritarianism needs further clarification. All definitions describe democracy at minimum as a political system that provides citizens with political rights which they are free to exercise in a structure open to public participation and electoral competition. This procedural 
description of democracy, however, is complemented by the pluralist approach to political competition, most prominently represented in Robert Dahl's conception of democracy as polyarchy, which requires that, in addition to the existence of an inclusive structure of public participation, an elected government must face a considerable degree of political contestation generated by the activities of other political and social forces during its tenure (Dahl, 1971, pp. 2-9; and 1982, p. 6). These two approaches to democracy differ as to whether government contestability is a constitutive part of 'empirical' democracy and must be included in the standards which political societies must meet in order to qualify as democracies, or whether it is simply a (desirable) outcome of political participation in a democracy. This differentiation poses a noticeable problem in empirical studies seeking to classify dominant party systems - political systems with a formal structure for public participation and a low degree of government contestability defined as the state of affairs in which, despite the presence of elections open to all parties, a single political force stays in power over a long period of time facing no serious challenge by other political forces with no foreseeable prospect of losing power due to persistently weak opposition from other political parties and civil society organizations.

A procedural approach of democracy would regard low levels of government contestability as a legitimate outcome insofar as the formal process of participation is open and participating citizens are unobstructed by typical authoritarian controls, which include direct interventions in formal processes of political participation such as the exercise of violence, physical threat or electoral fraud, barriers to entry targeting political opponents, banning political activities, the systematic harassment of the opposition and the censorship of political expression. In the procedural sense, whether citizens choose to contest or not contest is a matter of political behavior within the boundaries of democracy, as long as democratic process is open to participation. On the other hand, Dahl's polyarchy has a more demanding standard, according to which a regime that exhibits a low degree of government contestation is classified as an 'inclusive hegemony', a distinct political system that is open to citizens' participation but displays low levels of government contestability (Dahl, 
1971, pp. 8, 34). Here, the observed pattern of political behavior, i.e. a limited degree of government contestability, is elevated to the standard defining the boundaries between democracies and non-democracies.

Defining the boundaries between democracy and authoritarianism has become a pronounced question in view of the fact that many contemporary dictatorships rely less on traditional repressive methods and, instead, use more extensively soft manipulation and co-optation tactics to thwart political competition (Boix and Svolik, 2013; Gerscheweski, 2013; Franz and Kendall-Taylor, 2014). Dictators allow regularly-held elections and the existence of political parties in order to mimic democracies, with the purpose of legitimizing and retrenching their regimes (Ezrow and Frantz, 2011). Following this trend, a political force can become dominant by primarily relying on co-optation and discrimination in the allocation of economic and social resources, while making very little use of the conventional methods of political repression. As a result, these 'low-repression' 'low-contestability' regimes are the 'greyest' political systems for the purpose of classification, as the next section indicates. Can we characterize these systems as authoritarian even if the recorded level of repression is low and the leaders can be voted out of office?

Leaders who enjoy high popularity scores in regimes where the observed electoral irregularities are not significant enough to distort actual voting preferences may claim that their political dominance is the result of their popularity and not the outcome of any observed 'unsystematic' flaws in the dimension of political participation (Cf. Duvanov, 2013). Existing accounts in the literature have responded to this claim by stating that the elections held are unfair primarily as the result of soft manipulation of electoral behavior. But in theoretical terms, the notion of fairness has not yet been fully specified - particularly in terms of how these unfair practices differ in relation to known pathologies observed in several modern democracies. In this regard, extending the boundaries of non-democracy too far to cover this type of regime can be criticized for conceptual stretching. What is missing is an argument explaining why a limited degree of government contestability stemming from 
formally open elections is a dimension of political regime classification distinguishing democracy from authoritarianism - and not just a dimension of political behavior.

The contribution of this article is that it aims to tackle this definitional problem by addressing the source of this conceptual ambiguity: ascertaining the way methods other than overt repression restrict rather than just influence political behavior and answering the question which state of affairs in political competition obstructs effective political participation. A stronger argument here will allow researchers to disqualify 'low-repression, low-contestability' regimes from the class of democracies without any need to scrutinize how extensively and systematically they have relied on typical authoritarian controls in order to directly restrict political participation.

This article extends the concept of authoritarianism to include the use of soft tactics of political manipulation, such as co-optation in patron-client relations and its flip side, discrimination in the allocation of economic and social resources. It argues that conceptualizing democracy in purely procedural terms fails to capture how these tactics serve as informal restrictions to effective political competition in a formally open political system. It defends the view that authoritarianism can be conceptually broadened to include the input of informal socioeconomic sanctions in altering the opportunities for effective political participation. The article then juxtaposes and evaluates the procedural definitions and the pluralist approach to democracy. It explains why Dahl's conception of democracy is more realistic about how a modern political system can empower its citizens and protect them from domination by a single political force.

\section{Conceptual ambiguity over the status of contestability: implications for regime classification}

In procedural terms, democracy is defined as a system that provides citizens with regular institutional opportunities to change the governing officials and a political 
mechanism that allows the population to influence major decisions and choose among various contenders for political office (Lipset, 1960, p. 45). This system requires fair, honest, and periodic elections in which candidates freely compete for votes and in which virtually all the adult population is eligible to vote (Huntington, 1991, p. 7). The procedural approach to democracy is represented by Schumpeter's democratic method as an 'institutional arrangement for arriving at political decisions in which individuals acquire the power to decide by means of a competitive struggle for the people's vote' (Schumpeter, 1942/1976, p. 269). In a democracy, political rights and civil liberties must be widely protected, including the freedom of the press, the freedom of association and the freedom to criticize the government without fear of reprisal, while the elected authorities must possess real power to govern and should not be subjected to the control of the military or the clergy (Levitsky and Way, 2002, p. 53). Several procedural definitions further elaborate on the specific procedural requirements which a political system must meet: both the chief executive and the legislative bodies are elected in regular popular elections, more than one party exists, all opposition forces are allowed to form independent parties and compete in elections, and the incumbent does not engage in outcome-changing electoral fraud (Przeworski et al., 1996, pp. 3-36). Insofar as citizens freely register their preferences without fear of suppression and intimidation and these preferences are not distorted by electoral fraud, this political system is a democracy. A more minimalist version of the procedural approach describes democracy as a political system in which the body of citizens has the capacity to peacefully overthrow their rulers without a violent revolution - a possibility that in all other regime types takes place through the use of force (Popper, 2002, p. 132. José Cheibub, Gandhi and Vreeland, 2010, p. 74).

The procedural approach to democracy has been considerably modified by Robert Dahl who introduced the notion of polyarchy to describe actual political systems that meet what he viewed as 'necessary' yet 'probably not sufficient' conditions for ideal democracy: inclusive participation and public contestation (Dahl, 1971, pp. 2-9; 1982, p. 6). Like the procedural definitions of democracy, Dahl's polyarchy requires 
that an open structure of participation offer its citizens civil liberties and political rights but, in addition, it makes contestability a definitional part of the concept of democracy. The political system must not simply permit the presence of an opposition but the participants in the political process must make use of real opportunities to challenge the incumbent with relatively strong opposition parties and autonomous civil society organizations.

This view of democracy encapsulates a quintessentially pluralist view of politics according to which political participation is a necessary but not sufficient condition of democracy, and government contestability must be an integral component of democracy. This position elevates a dimension of observed political behavior into a standard of regime classification, placing a higher threshold for actual political systems to pass in order to qualify as democracies: they must exhibit both inclusive participation and a good degree of public contestation, or in other words, they must not just offer an open structure of political competition, they must be characterized by a significant degree of political competitiveness (Sartori, 1976/2005, p. 194). Political contestability presupposes that collective organizations - active political parties, civil society organizations, labor unions and other professional associations are autonomous from both the government and the government party, that they enjoy free access to independent sources of information and that they do indeed activate their democratic rights and freedoms (Dahl, 1971, p. 3). Political parties and other organizations must be capable of articulating their preferences in public debate, mobilizing support and disseminating their political messages. The exercise of political rights and civil liberties improves both the inclusiveness of the political system and the degree of government contestability (Dahl, 1971, pp. 4 and 14), but the latter can vary independently in instances in which political inclusion does not generate a considerable degree of public contestation. Dahl coined the term 'inclusive hegemony' as a system that is inclusive in procedural terms but offers limited or virtually no opportunities for public contestation (Dahl, 1971, pp. 5 and 9). While there is a large space between the extreme values of full or no inclusion and full or no contestation, regimes that come close to these 'poles' can be seen as 
'nearly' polyarchical or 'nearly' hegemonic (Dahl, 1971, pp. 8-9). The exact boundaries are not well specified, yet it follows that regimes that are "nearly hegemonic' are not democracies.

The two approaches to democracy generate conceptual ambiguity over the status of dominant party systems. The dominant position of a single political force is manifested in the length of incumbency, its duration in office, the size of parliamentary majorities, the size of the minority parties (Bogaards, 2004; Bogaards, and Bouçek, 2010) and the strong impact its government policies have on the national political agenda (Pempel, 1990, pp. 1-32, 4-4). In both accounts, dominant party systems that exhibit serious flaws in the operation of its political process will be classified as authoritarian; for instance, when the government party resorts to the systematic application of physical violence, electoral fraud and political intimidation or takes measures that selectively ban opposition parties or candidates from standing for election. This includes incumbents who are ready to call off elections if they anticipate a defeat or refuse to surrender power after a defeat (Cheibub, Gandhi and Vreeland, 2010, p. 70). Where regime classification has been inconclusive is about the status of dominant party systems that offer a formally open structure of public participation, the leadership makes no systematic use of typical authoritarian tools but the incumbent's electoral defeat seems to be very unlikely in the near future (Pempel, 1990; Giliomee and Simkins, 1999).

From a procedural perspective, a political system that exhibits low levels of government contestability is democratic insofar as this state of affairs is the result of the free exercise of citizens' rights on the grounds and reflects their own free will (Arian and Barnes, 1974, p. 593). In procedural terms, as long as there are fully available formal rights offering citizens opportunities for participation which citizens have indeed exercised without restraint, it can be said that the electorate has freely chosen to elect a single party or a presidential candidate with an overwhelming majority and it has consequently allowed it to stay in government for a relatively longer period of time. In this view, a low degree of government contestability can be 
seen as a legitimate outcome of that process as long as political rights and civil liberties are respected and there has been no use of typical authoritarian controls. One-party dominance may be an indication of increased party effectiveness in conditions of open political competition (Dunleavy, 2010), while the recurrent weakness of the opposition and civil society organizations can be attributed to their incapacity to articulate an equally appealing policy agenda.

On the other side, regime classifications inspired by Robert Dahl's 'inclusive hegemony' would classify actual party systems as authoritarian not only when direct interventions block or distort citizen's participation but also when, despite the holding of competitive multiparty elections, other political forces consistently fail to act as effective competitors of the dominant party or president and have no hope of coming to power (Sartori 1976/2005, p. 173; Ware, 1996, pp. 159 and 165). Possible prominent cases include Belarus under Lukashenka (Korosteleva, 2003), Singapore under the People's Action Party (Barr, 2014), Malaysia under the Barisan Nasional (Wong, Chin and Othman, 2010), Venezuela under Chavez (Corrales and PenfoldBecerra, 2007) and Russia under Putin (Balzer, 2003; Colton and McFaul, 2003). In such cases, voting and, often, popular referendums reconfirmed the popularity of the leaders but they were conducted in conditions of mass-scale co-optation and socioeconomic pressure targeting the opposition and civic society organizations.

This type of regime is the greyest conceptual category among a variety of regimes dubbed with terms such as illiberal democracies (Zakaria, 1997), demagogical democracies (Korosteleva, 2003), managed democracies (Colton and McFaul, 2003), defective democracies (Croissant, 2004; Merkel, 2004), semi-democracies (Gaziorowski, 1996) or, on the other side, with labels evocative of authoritarianism such as competitive authoritarianism (Levitsky and Way, 2010), electoral authoritarianism (Schedler, 2006; 2009; Levitsky and Way, 2010; Linz and Stepan, 1996), hegemonic regimes (Diamond, 2002), semi-autocratic regimes (McFaul, 2005) and sultanistic regimes (Eke and Kuzio, 2000). The absence of a clear demarcation line separating democracy from authoritarianism has left a large space 
for ill-defined and overlapping regime typologies reflecting subjective and highly debatable views of democracy that 'mask' rather than solve the problem of conceptual ambiguity (Armory and Schamis, 2005; Munck, 2006; Storm, 2008, p. 217). Part of the problem is associated with the different status of contestability in procedural and pluralist approaches of democracy and the resulting confusion with regard to the democratic credentials of dominant party systems with an open political process, a low degree of government contestability and limited possibility for alternation in office.

Regime classification faces this problem whether it follows a dichotomous view of democracy versus authoritarianism (Huntington, 1991, p. 11; Przeworski et al., 2000; Cheibub et al., 2010), or adopts a continuous view of regime variation along a range between democracy and authoritarianism upon which actual political regimes can be placed on the basis of their performance (Dahl, 1971, p. 9; Bogaards, 2010). Continuous strategies have to set up thresholds over the length of the distance that exists between the 'poles' of democracy and authoritarianism (Schedler, 2002, pp. 36-50; Munck, 2006, p. 28; Gilbert and Mohseni, 2011). Contestation can be taken as one of several dimensions that measure democracy along a continuum towards authoritarianism, and regime subtypes can be formulated following scales of measurement. Judged by their performance on contestability some dominant party systems will be classified as democratic, others as authoritarian and some will be positioned as 'in-between' or 'hybrid' regimes. Dichotomous approaches must also specify a threshold along the dimension of contestation below which a dominant party system will fall outside the category of democratic regimes. Either way, dichotomous and continuous strategies of regime classification must first define whether low government contestability must be placed inside or outside the conceptual boundaries of democracy.

This problem is also visible on the part of the literature seeking to define the concept of dictatorship. Is a dictatorship a regime that represents only 'the preferences of a sub-group of the population, as Acemoglu and Robinson claim (2006, p. 17; a 
procedural view by Brooker too, 2000, p. 3)? If this is the case, dominant party systems with a popular leadership are left outside this definition. If democracy is a system in which the whole population has been given a say in the selection of the leader who can only be elected with the support of a winning coalition consisting of a plurality of votes (Bueno de Mesquita et al., 2003), dominant party systems of the type described earlier are democracies with a number of procedural flaws. For other scholars, however, single-party dictatorship exists even in the presence of elections if one political party remains in office uninterruptedly, holding regular multi-party elections and winning supermajorities while considering using repression as the last resort (Magaloni, 2006, p. 32). Moreover, the degree of contestability between elections during tenure is relevant if authoritarian regimes are defined as systems with limited, non-responsive political pluralism (Linz, 1975, p. 255) and the definition of pluralism covers not just public participation but also the actual degree of government contestability. But contestability between elections is irrelevant if we stick to the definition that dictatorships lack contested elections altogether (Przeworksi et. al., 2000, p.15).

\section{Limited contestability and the notion of informal authoritarian controls}

Whether a low degree of government contestability - in the presence of formal participatory opportunities - suffices to disqualify political systems from the category of democracy or whether it must be viewed as a legitimate outcome of political behavior is an issue that can be addressed by examining the close connection between what influences political behavior and how the nature of this influence qualifies the character of the political system itself. In this direction, Sartori talks about the existence of 'equal opportunities' that enable effective political contestation and argues that a sizeable voting distance separating the government party from the main opposition party does not suffice to classify a party system as 
hegemonic (Sartori, 1987, p. 201). If the major party is consistently supported by the winning majority of the voters and other parties exist as legal and legitimate - if not necessarily effective - competitors, this is a democratic system, which Sartori called a 'predominant' party system (Sartori, 1987, p. 195). By contrast, a 'hegemonic' party system only allows other parties to operate so long as they do not come close to gaining power. What distinguishes a hegemonic party system from a predominant party system is that in the latter 'alteration in power is not ruled out and the political system provides ample opportunities for open and effective dissent' (Sartori, 1987, p. 200). Sartori, however, does not clarify which practices help a party's strategy become predominant and which practices deprive the opposition of real opportunities to contest the government, effectively ruling out alteration in power and sustaining hegemony.

Scholars of democracy have addressed this question by assessing the 'fairness' of the political process and developing a broader view of authoritarian manipulation. Politically dominant leaders may allow regularly-held elections and competition from political parties to mimic democracies but these pseudo-democratic institutions serve to legitimate the system and demonstrate the popularity of the ruling group (Schedler, 2006; Ezrow and Frantz, 2011; Frantz and Kendall-Taylor 2014). In that context, limiting the degree of government contestability may primarily rely on soft manipulative tactics such as clientelism, pork-barrel politics, excessive rent distribution and state propaganda (Magaloni, 2006; Levitsky and Way, 2010; Gerschewski, 2013). Unlike typical authoritarian tools, these practices do not impose direct restrictions to the formal structure of participation but they, nonetheless, act as socioeconomic pressure that affects choices of political behavior, undermining the integrity of elections and leading to 'electoral authoritarianism' (Schedler, 2006; 2009). In this view, the electoral playing field is skewed in favor of the ruling party (Levitsky and Way, 2010) and multi-party electoral competition actually 'masks the reality of authoritarian domination' (Diamond, 2002, p. 24; Linz, 2000, p. 159). In that light, a dominant system can be regarded as an authoritarian regime when the cost imposed on supporting the opposition is high, pervasive and fundamentally 
important in altering the participation decisions of prospective political activists (Greene, 2010, p. 810).

From the procedural approach to democracy, however, regarding soft manipulative practices as equivalent to typical authoritarian controls directly restricting political behavior can be seen as a case of 'conceptual stretching'. This is because soft manipulative practices such as patronage supply, the use of state resources generating incumbent campaign advantages, the manipulation of the economy (through government spending following the electoral cycle, and pork-barrel distributions), or even vote-buying and informal employment blacklisting have been extensively used in democracies too. It is problematic to equate these practices with typical authoritarian controls, since they do pose formal restrictions to political participation and they do not coerce voters with physical violence, penalties and legal sanctions. In this view, while practices of soft manipulation generate flaws in the quality of political competition, they can be seen as pathologies of a working democracy, if the political system maintains an open and inclusive structure of political participation and the electoral outcome genuinely reflects the popularity of the incumbent without any electoral irregularities distorting the electoral result. In essence, dominant parties whose electoral strategies primarily or exclusively rely on these practices enjoy a higher degree of incumbent advantage than government parties in multi-party systems (Cf. Treisman, 2011), and the emergent political system may be classified, at most, as a flawed or 'managed' democracy depending on the extent to which these soft manipulative practices are used.

The issue is, therefore, to specify under which circumstances soft manipulation practices can be equated to authoritarian controls restricting political behavior, rather than just influencing it, which would then define accordingly the nature of the regime that uses them as authoritarian. Political hegemony, attained by soft manipulative practices, understandably raises questions about the actual degree of competition permitted by the system (Huntington, 1991, p. 7). It is plausible to imagine circumstances in which soft manipulative practices act similarly as coercive controls 
and can be equated with typical authoritarian methods of restricting political behavior when, under certain conditions, serve as socioeconomic sanctions on dissenting political behavior with a scale and intensity that produce an adjustment of citizens' decisions similar to the behavioral response that is triggered by fear of systematic violent repression in typical authoritarian regimes (Trantidis, 2015). The threshold after which 'soft' manipulative political methods act as effective limitations to political participation and work in ways comparable to coercion in typical authoritarian systems can be placed in the absence of 'exit' for the targeted citizens. Fear of reprisal allows these practices to operate as effective socioeconomic penalties placing informal restrictions to public participation. In these circumstances, these strategies can be conceptually equated with typical authoritarian coercion in a way compatible with the procedural definition of democracy, on the basis that restrictions to political participation can take any form of pressure that involves intimidation and the threat of punishment, whether it is imprisonment, violence or inescapable damage from socioeconomic penalties.

This line of argument raises an objection to the democratic credentials of a dominant party system in procedural terms and brings our attention to the informal mechanisms obstructing political behavior and thereby limiting democratic participation and fundamentally altering the meaning of elections into a mechanism for 'legitimation, patronage and elite management' (Morgenbesser, 2014). It thus builds 'a conceptual bridge' between the procedural definition of democracy and Dahl's position on contestability.

\section{Contestability as a minimal standard for democracy}

While the conception of soft manipulative practices as authoritarian under certain circumstances broadens the boundaries of authoritarianism to include dominant party systems that make a systematic use of them, it does not solve the definitional question about democracy. Various definitions draw on different normative visions of which ideal state of affairs political systems must meet: what the necessary 
ingredients of a democratic political structure should be. This diversity essentially compels us to adjudicate between competing value judgments. The problem is that normative conceptions are not commensurable against one another in order to enable some form of objective comparative evaluation, and it is thus difficult to find a neutral arbiter for dissimilar value judgments. However, the previous discussion on the practices that effectively restrict political participation under a facade of 'democratic institutions' points to the direction that can help us address the definitional problem in greater depth - whether government contestability as a state of affairs is a constitutive property of a democratic political system.

The benchmark for this comparative evaluation can be found in the basic democratic ideal which different visions of democracy consider to be the state of affairs which a democracy must reach at a minimum. 'This 'lowest common denominator' is present in the etymology of democracy - consisting of the words demos, the citizenry, and kratos, power - and entails the vision of popular sovereignty as the subjugation of political power (kratos) to those upon whom it is exercised (the demos). These two notions of different visions of 'ideal' democracy have historically stood in an antithetical relation: on the one side, political power, which is authoritative, binding and all-encompassing within a given jurisdiction and, on the other, its subjects - the body of citizens. Democracy thus places a difficult target, to achieve a synthesis of the antithesis in a system of governance that must adequately empower the body of citizens (demos) so that they could exert a substantial degree of influence on state power (kratos), and at the same time it will protect them from the usurpation of power by a single group who would wish to impose its will on all others (becoming the 'kratos' itself). Democracies must approximate these two basic conditions: citizen's political empowerment and protection from domination by a group or a coalition of groups. Both the procedural and the pluralist conceptions of democracy put forward their own thesis on how contemporary political societies can meet these standards; the former focuses on procedural requirements while the latter adds the dimension of contestability. The two approaches can thus be assessed and compared on the basis of how realistic their prescriptions are in achieving political 
empowerment and preventing political domination, given the pragmatic terms in which political competition takes place.

\section{How political empowerment is attainable}

Procedural definitions of democracy convey confidence in the capacity of political systems with fully respected civil rights and free elections to enable citizens to exercise effective control over political power and exert influence on policy outcomes. This political system approximates the ideal of 'popular sovereignty', insofar as "public policies are determined either directly by the vote of the electorate or indirectly by officials freely elected at reasonably frequent intervals and by a process in which each voter who chooses to vote counts equally' (Pennock, 1979, p. 7). In this political system, leaders and organizations 'define the alternatives of public policy in such a way that the public can participate in the decision-making process' (Schattschneider, 1960, p. 141). For Schumpeter, for instance, the democratic process is 'the institutional arrangement for arriving at political decisions, which realizes the common good by making the people itself decide on issues through the election of individuals who are to assemble in order to carry out its will' (Schumpeter, 1942/1976, p. 250, emphasis added). An open process for political participation and expression can also help citizens achieve even broader ambitions with regard to what they view as ideal patterns of social development. Democracy as 'government by the people' allows the development of human capacities to the utmost, through free and full discussion of common problems and interests (Pennock, 1979, p. 7).

This process tends to generate a competitive political system, as actors and groups will most likely articulate competing claims, and leaders and organizations propose alternatives of public policy in such a way that the public can choose and shape by taking part in the decision-making process (Schattschneider, 1960, p. 141). The most

probable outcome of civic participation would be a high degree of political competitiveness as the result of the activities of social actors endowed with political 
rights to propose and react to policy initiatives. This state of affairs generates an inherently competitive political arena.

The fact that social heterogeneity, when unobstructed by authoritarian controls, tends to generate a high degree of political competition, invites us to see the political process through the lens of political pluralism. Central to the pluralist conception of politics is that a society inhabited by heterogeneous and often conflicting interests will tend to generate rival organizations, political parties and factions with a diversity of preferences and identities. In the pluralist approach of politics democratic politics is essentially 'competition among active democratic minorities, where a minority becomes a majority, or, inversely, the majority is thrown into a minority' (Sartori, 1967, p. 116). Democratic participation is effectuated through organizational pluralism primarily through the activities of political parties and, equally importantly, through the activities of other social groups such as unions, lobbies, professional associations etc. Political pluralism understands political competition as a struggle for power among groups whose outcome is primarily determined by the dynamics of collective action: shifting alliances and the distribution of resources. In that light, the 'demos' is seen not as a single collectivity with a dominant will which the democratic process is supposed to identify and promote but, rather, it is a community consisting of competing social and political actors whose interests they primarily express and pursue by means of collective action. Social actors in competition with one another will form active groups on the basis of shared preferences to engage in collective action. Resource endowments define the capacity of each political organization to effectively perform the tasks necessary for success in the political arena. This is equally true for political parties that represent bundles of political and ideological preferences. Political parties must possess and utilize material resources and recruit and mobilize active members in order to galvanize broader electoral support.

This perception of democratic politics indicates why organizational pluralism is the structure that sustains the viability of political competition in large-scale political 
systems on which isolated citizens cannot exert much influence (Dahl, 1982, p. 12). While elections and participatory processes generate a set of opportunities available to citizens, it is collective action through which citizens become effective participants with the capacity to influence the political agenda in complex decisionmaking processes. Hence, the pluralist view goes a step further: political rights equally distributed among its constituent citizens are mostly valuable exactly because they generate a free arena for the collective expression of conflicting social interests in the sphere of politics. The ideal of popular sovereignty - the synthesis of the antithesis - is achievable only to the extent that in a competitive political arena, social actors, by pooling their resources, can become effective political participants and may even overcome structural disadvantages which they face as individuals. Democracy through the pluralist lens is not reduced to the presence of formal rights and free, fair, and recurring elections, but it involves the active expression of multiple interests through collective action and with autonomous sources of information (Morlino, 1986, p. 54). Unlike the procedural approach to democracy, this pluralist view endorses a definition of democracy in which the presence of a strong opposition and regular alternation of parties in government is its necessary component (Cf. Przeworski et al., 1996; Giliomee and Simkins, 1999). Limited contestability in an otherwise open structure of participation can only be seen as a serious anomaly, given the presence of heterogeneous interests and conflicting claims, and this state of affairs points to the existence of strong informal barriers to the collective expression of citizens and significant asymmetries in the availability of resources to the opposition forces and civil society organizations.

Encapsulating the pluralist view of the social world, polyarchy explicitly highlights the long distance which an actual political system should travel to approximate the ideal of the 'rule of the demos'. By acknowledging the reality of the numerous affiliations and multiple preferences of the citizens, polyarchy breaks down the notion of demos into its constituent parts, the polloi who articulate competing claims in politics through collective action. Relatively autonomous organizations are a necessary component of democracy, 'both as a prerequisite for its operation and as 
an inevitable consequence of its institutions (Dahl, 1982, pp. 5, 11, 50, 36). This is a pragmatic thesis on how modern societies can meet basic normative conditions for democracy in the real context of inter-group antagonisms and power asymmetries.

How citizens' defense from political domination is feasible

The second requirement of democracy is that citizens must be protected from domination by a single group or a coalition of groups so that democracy would not degenerate into oligarchy. Procedural definitions of democracy put faith in the capacity of an open structure of participation to prevent this outcome thanks to equally distributed political rights and civil liberties that allow citizens to exercise considerable control over the structure of collective decision-making in their capacity as voters or members of parties and other social groups. Modern democracy offers 'a variety of competitive processes and channels for the expression of interests and values' (Schmitter, and Karl, 1991, p. 78). In this view, democratic rights and institutions set in motion and safeguard a free sphere of political participation.

This procedural standard, however, almost tautologically equates democratic institutions with the absence of domination: citizens unobstructed by repression, intimidation and manipulation will be free to participate in politics and express their views. Process leads to outcome. Does this premise fully capture the conditions necessary for organizational pluralism to emerge, flourish and survive, as discussed previously? Concentrations of organizational resources can effectuate one-group dominance even under the strictest procedural rules of participation and constitutional safeguards of the Madisonian type. Procedural definitions of democracy cannot capture the possibility that a group or a political party gets the critical advantage in terms of organization and resources and becomes politically dominant by effectively thwarting the organizational capacity of competing political forces (Dahl, 1982, p. 38). The definitions leave outside their conceptual lens the prospect of a single political force obtaining a hegemonic political position without placing formal limits to political participation. 
Robert Dahl described this possibility as the problem of democratic pluralism (Dahl, 1982). On the one hand, social diversity is expected to generate a substantive degree of political contestability in a genuinely open system of political participation while, on the other, it is possible that a procedurally democratic regime will degenerate into hegemony if one group or alliance of groups enjoys an advantage in organizational resources that no other alliance of social forces can rival. The systematic use of state resources by a political force with great intensity and on a large scale can produce through manipulation of political behavior - an effect on political competition similar to what coercion in a typically repressive regime leads to: authoritarian control over political behavior. This outcome is more likely to happen when a group gains monopoly access to state resources which by their own nature cannot be matched by any other pool of resources. Hence, in the pluralist view of democracy, political rights and civil liberties rights, albeit a necessary condition for democracy, give each citizen a modicum of influence over political decision-making (Dahl, 1971, pp. 1213). It is collective action that gives citizens the actual capacity to influence political processes as well as the organizational ability to contest the use of state power and protest against its abuses. As evidence has shown, mass participation and party competition has been more effective than procedural checks in diminishing the use of repression by a dominant political force holding elections (Davenport 2007, p. 115).

The pluralist approach tells us how the reverse of the democratic ideal, namely domination by one group, can occur even when a formally open democratic process is in place. The question of how to subordinate political power to people, and achieve the institutional synthesis of 'kratos' and 'demos', is recast as the issue of preserving organizational pluralism: how vertical power relations between individuals and state power and horizontal power relations among citizens and their groups must be configured so that politics remains a neutral arena for diverse social groups to compete over policy (Truman, 1951; Latham, 1952; Dahl, 1961). This presupposes a balance of power in which no group gains an unparalleled resource advantage that would give it control over the whole political system, the state and its bureaucracy. 
In that state of affairs, attempts by one group to dominate will be prevented by the collective organization of others (Dahl, 1971, pp. 15-16, and 48). In party politics, this means that the strength of the government party can be offset by the organizational strength of the opposition forces. Insofar as collective action in a political society is constantly reconfigured in a way that the distribution of power resources among competing groups is more or less symmetrical, this will generate a system of 'mutual controls' and this system can sustain democracy (Dahl, 1982, pp. $32,34,36,43)$. In this pluralist view, contestability both safeguards democracy and is identified with it conceptually. Hence, it must not just be seen as a derivative of the democratic process but must be placed as a constitutive element of its very definition.

\section{Conclusion}

Whether the position of government contestability is a constitutive part of the definition of democracy or not has created noticeable ambiguity regarding the democratic credentials of dominant party systems that limit their exposure to political contestation not by the systematic use of repressive tactics but by primarily relying on co-optation and soft manipulation. To classify these regimes, the article addresses the source of this conceptual ambiguity: a) whether low contestability is a legitimate outcome of democratic process or a fault of the political system that places it outside the boundaries of democracy and b) whether practices other than repression - which are employed to limit contestability - are interventions simply on the dimension of political behavior or affect the dimension of political regime classification too.

The article argues that, besides direct repression, soft manipulative tactics limiting government contestability may actually restrict free political participation in ways similar to typical authoritarian controls, and can thus be equated with typical authoritarian controls. This enables classifying the regimes that primarily rely on these tactics as authoritarian. It also argues that Dahl's polyarchy captures the full 
distance which political societies must travel to meet the basic standards of democracy. Polyarchy understands that political power stems from collective organization in political parties and civil society organizations and has a wider grasp of the actual limits to political empowerment that can lead to one-group domination in a formally open democratic system. Polyarchy also offers an elaborate view of how domination is possible in a system open to political participation and indicates how this prospect can be prevented in the context of organizational pluralism. A group in control of the state's unmatched resources for manipulation can skew the pattern of collective action in its favor. This state of affairs allows a single political force to dominate over all others. In this regard, lack of government contestability implies that there are serious deficiencies in the structure of political organization associated with informal restrictions to effective political participation.

Hence, government contestability is necessary for citizens in order to exert political influence and protect themselves from political domination, which is the minimum that a democracy can offer. Contestability is not simply a desirable outcome of the democratic process but a constitutive part of the definition of democracy.

The procedural approach is not necessarily incompatible with the pluralist view of political reality, but by omitting to incorporate it explicitly as an integral part of the definition of democracy, it ignores crucial parameters of collective action which serve as vehicles of civic empowerment as well as tactics other than direct repression that pose informal restrictions to effective political participation. Because of this omission, any effort to define democracy in strictly procedural terms can easily overlook how a political force can establish a hegemonic position in a formally open political system.

\section{References}

Arian, A, and Barnes, S. (1974) 'The Dominant Party System: A Neglected Model of Democratic Stability', The Journal of Politics 36 (3), pp. 592-614. 
Armory, A. Schamis, H. (2005) 'Babel in Democratization Studies', Journal of Democracy 16 (4), pp. 113-128.

Balzer, H. (2003) 'Managed Pluralism: Vladimir Putin's Emerging Regime, PostSoviet Affairs 19 (3), pp. 189-227.

Barr, M. (2014), 'The Bonsai under the Banyan Tree: Democracy and Democratisation in Singapore', Democratization 21 (1), pp. 2014.

Bogaards, M. (2004) 'Counting Parties and Identifying Dominant Party Systems in Africa', European Journal of Political Research 43 (2), pp. 173-197.

Bogaards, M. (2010) 'Measures of Democratization: From Degree to Type to War', Political Research Quarterly 63 (2), pp. 475-488.

Bogaards, M., and Bouçek F. (2010) Dominant Political Parties and Democracy, London: Routledge.

Boix, C. and M. Svolik. (2013) 'The Foundations of Limited Authoritarian Government: Institutions, Commitment, and Power-Sharing in Dictatorships', Journal of Politics 75 (2), pp. 300-316.

Brooker P. (2000) Non-Democratic Regimes: Theory, Government, and Politics, London: Macmillan.

Bueno de Mesquita, B., Smith, A., Silverson R. And Morrow J. (2003) The Logic of Political Survival, Boston MA: MIT Press. 
Cheibub, J., Gandhi J. and Vreeland J. R. (2010) 'Democracy and Dictatorship Revisited', Public Choice 143 (1-2), pp. 67-101.

Wong C., Chin J. and Othman N. (2010), 'Malaysia - Towards a Topology of an Electoral One-Party State', Democratization, 17 (5), pp. 920-949.

Colton T. and McFaul, M. (2003) Popular Choice and Managed Democracy: The Russian Elections of 1999 and 2000, Washington DC: Brookings Institution Press.

Corrales, J. and Penfold-Becerra M. (2007) 'Venezuela: Crowding Out the Opposition', Journal of Democracy 18 (2), pp. 99-113.

Croissant, A. (2004), 'From Transition to Defective Democracy: Mapping Asian Democratization', Democratization 11 (5), pp. 156-178.

Davenport, C. (2007) State Repression and the Domestic Democratic Peace, New York: Cambridge University Press, 2007.

Dahl, R. (1961) Who Governs? Democracy and Power in an American City, New Haven: Yale University Press.

Dahl, R. (1971), Polyarchy: Participation and Opposition, New Haven, CT: Yale University.

Dahl, R (1982) Dilemmas of Pluralist Democracy: Autonomy vs. Control, New Haven: Yale University Press.

Diamond, L. (2002) 'Elections without Democracy: Thinking About Hybrid Regimes', Journal of Democracy 13 (2), pp. 21-35. 
Duvanov, S. (2013) Kazakhstan: Cunning Democracy'. Oslo: Norwegian Helsinki Committee and Freedom House.

Dunleavy, P. (2010) 'Rethinking Dominant Party Systems', in M. Bogaards and F. Bouçek (eds.), Dominant Political Parties and Democracy, London: Routledge, pp. 23-44.

Eke, S. and Kuzio T. (2000) 'Sultanism in Eastern Europe: The Socio-Political Roots of Authoritarian Populism in Belarus', Europe-Asia Studies 52 (3), pp. 523-547.

Ezrow N. and Frantz, E. (2011) 'State Institutions and the Survival of Dictatorships', Journal of International Affairs 65 (1), pp. 1-13.

Frantz, E and Kendall-Taylor A. (2014) 'A Dictator's Toolkit: Understanding How Co-optation Affects Repression in Autocracies', Journal of Peace Research 51(3), pp. 332-346.

Gaziorowski, M. (1996) 'An Overview of the Political Regime Change Dataset', Comparative Political Studies 29 (4): pp. 469-483.

Gerschewski, J. (2013) 'The Three Pillars of Stability: Legitimation, Repression, and Co-optation in Autocratic Regimes', Democratization 20 (1), pp. 13-38.

Gilbert, L. and Mohseni, P. (2011) 'Beyond Authoritarianism: The Conceptualization of Hybrid Regimes', Studies in Contemporary International Development 36 (3), pp. 270-297.

Giliomee, H. and Simkins, C. (1999) The Awkward Embrace: One-Party Domination and Democracy, Australia: Harwood Academic Publishers. 
Greene, K. (2010) 'The Political Economy of Authoritarian Single-Party Dominance', Comparative Political Studies 43 (7), pp. 807-834.

Huntington, S. (1991) The Third Wave: Democratization in the Late Twentieth Century, Norman: University of Oklahoma Press.

Korosteleva, E. (2003) 'Is Belarus a Demagogical Democracy?', Cambridge Review of International Affairs 16 (3), pp. 525-533.

Latham, E. (1952) 'The Group Basis of Politics: Notes for a Theory', American Political Science Review 46 (2), pp. 376-97.

Levitsky, S. and Way L. A. (2002) 'The Rise of Competitive Authoritarianism', Journal of Democracy 13 (2), pp. 51-65.

Levitsky, S. and Way L. A. (2010) Competitive Authoritarianism: Hybrid Regimes After the Cold War., Cambridge: Cambridge University Press.

Linz, J. (2000/1975) Totalitarian and Authoritarian Regimes, Boulder CO: Lynne Rienner.

Linz J. and Stepan A. (1996) Problems of Democratic Transition and Consolidation: Southern Europe, South America, and PostCommunist Europe, Baltimore, MD: Johns Hopkins University Press.

Lipset, S. M. (1960) Political Man: The Social Bases of Politics, London: Heinemann.

Magaloni, B. (2006) Voting for Autocracy: Hegemonic Party Survival and its Demise in Mexico, Cambridge: Cambridge University Press. 
McFaul, M. 2005. 'Transitions from Postcommunism', Journal of Democracy 16 (3), pp. 5-19.

Merkel, W. (2004) 'Embedded and Defective Democracies', Democratization 11 (5), pp. 33-58.

Morgenbesser, L. (2014). 'Elections in Hybrid Regimes: Conceptual Stretching Revived', Political Studies 62 (1), pp. 21-36.

Morlino, L. (1986) 'Democratic Establishments: A Dimensional Analysis', in E. A. Baloyra (ed.) Comparing New Democracies: Transition and Consolidation in Mediterranean Europe and the Southern Cone, Boulder: Westview Press, pp. 53-78.

Munck, G. (2006) 'Drawing Boundaries: How to Craft Intermediate Regime Categories' in A. Schedler (ed.), Electoral Authoritarianism: The Dynamics of Unfree Competition, Boulder, CO: Lynne Rienner, pp. 27-40.

Pempel, T. J. (1990) 'Introduction', in . J. Pempel (ed.), Uncommon Democracies: The One-Party Dominant Regimes, Ithaca, NY: Cornell University Press, pp. 1-32.

Pennock, J. R. (1979) Democratic Political Theory, Princeton: Princeton University Press.

Plamenatz, J. (1978) Democracy and Illusion: An Examination of Certain Aspects of Modern Democratic Theory, London: Longman.

Popper, K. (2002) The Open Society and Its Enemies: The Spell of Plato, London: Routledge. 
Przeworski, A, Alvarez, M. Cheibub J. A. and Limongi F. (1996) 'Classifying Political Regimes', Studies in Comparative International Development 31 (2), pp. 336.

Przeworski, A, Alvarez, M. Cheibub J. A. and Limongi F. (2000) Democracy and Development: Political Institutions and Well-Being in the World, 1950-1990, Cambridge: Cambridge University Press.

Sartori, G. (1967) Democratic Theory, New York, Washington, London: Praeger.

Sartori, G. (1987) The Theory of Democracy Revisited, Chatham, NJ: Chatham House.

Sartori, G. (1976/2005) Parties and Party Systems: A Framework for Analysis, Cambridge: Cambridge University Press.

Schattschneider, E. (1960) The Semisovereign People: A Realist's View of Democracy in America, New York: Holt, Rinehart and Winston.

Schedler, A. (2002) 'The Menu of Manipulation', Journal of Democracy 13 (2), pp. 36-50.

Schedler, A. (2006), 'The Logic of Electoral Authoritarianism', in A Schedler (ed.), Electoral Authoritarianism: The Dynamics of Unfree Competition, Boulder, CO: Lynne Rienner Publishers, pp. 1-26.

Schedler, A. (2009) 'Electoral Authoritarianism', in T. Landman and N. Robinson (eds.) The SAGE Handbook of Comparative Politics, London: Sage, pp. 381-393.

Schumpeter, J. (1942/1976) Capitalism, Socialism, and Democracy, New York: Harper 
Schmitter, P. and Karl, T. L. (1991) 'What Democracy is... and Is Not', Journal of Democracy 2 (3), pp. 75-88.

Storm, L. (2008) 'An Elemental Definition of Democracy and its Advantages for Comparing Political Regime Types', Democratization 15 (2), pp. 215-229.

Trantidis, A. (2013) 'Clientelism and the Classification of Dominant Party Systems', Democratization 22 (1), pp. 113-133.

Treisman, D. (2011) 'Presidential Popularity in a Hybrid Regime: Russia under Yeltsin and Putin', American Journal of Political Science 55 (3), pp. 590-609.

Truman, D. (1951) The Government Process: Political Interests and Public Opinion, New York: Alfred A. Knopf.

Ware, A. (1996) Political Parties and Party Systems, Oxford: Oxford University Press.

Zakaria, F. (1997) 'The Rise of Illiberal Democracy', Foreign Affairs 76 (6), pp. $22-$ 43. 